\title{
Biological responses of white sea bream (Diplodus sargus, Linnaeus 1758) and sardine (Sardine pilchardus, Walbaum 1792) exposed to heavy metal contaminated water
}

\author{
Giulia Guerriero',2* Samah M. Bassem², Fagr Kh. Abdel-Gawad²* \\ ${ }^{1}$ EClab, Department of Biology, University of Naples, Federico II, Naples, Italy, ${ }^{2}$ Department of Water Pollution, Centre of Excellence for \\ Advanced Science Research, National Research Centre, Dokki, Giza, Egypt
}

\section{A B S TR A C T}

\begin{abstract}
The aim of the present work was to assess, by rapid approach, the detoxification capacity and the genotoxicity caused by exposure of some marine fish to polluted waters. The fish species selected for the study: White sea bream (Diplodus sargus, Linnaeus 1758) and sardine (Sardine pilchardus, Walbaum 1792) were collected from different sites of Alexandria, El-Max bay and Bahary, in Egypt. Results of heavy metals analysis in sediment were: $\mathrm{Al}>\mathrm{Fe}>\mathrm{Cr}>\mathrm{Pb}>\mathrm{Hg}>\mathrm{Cd}$. Concerning detoxification analysis, fish collected from El-Max bay encounter the highest liver enzyme activity of Glutathione S-Transferase. Also, genotoxicity was evaluated in liver, gills and muscle of fishes collected and the results indicated that fish collected from El-Max bay has the highest levels of comets (DNA damage) when compared to the other sites selected as reference. It can be concluded from our results that the different tissues examined have alteration of level of detossification and comets as result of different degree of oxidative pollution insult. These biological responses may be considered for rapid extimation of food oxidative damage as well as for environmental quality.
\end{abstract}

Keywords: White sea bream (Diplodus sargus), Sardine (Sardine pilchardus), Glutathione-S-Transferase enzymatic activity; Comet assay; Food security

\section{INTRODUCTION}

Recently, the pollution of marine environment become a growing great problem for environmental quality and food security (Fasulo et al., 2015; Pecoraro et al., 2017, 2018; Adel et al., 2018). Although the presence of heavy metals in traces is of great importance to the aquatic life, the release of man's wastes into marine environment affects the normal characteristics of water, sediments, fauna and flora, and also may induce toxicity not only to the aquatic life but also reach human (Marti-Cid et al., 2007; Sharma et al., 2014; Piscopo et al., 2018). Accumulation of pollutants in fish and other aquatic biota provides an estimate of integrated metals exposure. Parameter as content of metals in seafood as well as daile intake pro die can garantie a safe diet (Adel et al., 2016; Adel et al., 2018). Nevertheless toxicological studies highlighted that they represent the most oral consumption at high risk for human reporting risk assessment and health implications (Conti et al., 2012; Sharma et al., 2014). Many studies were done to figure out the quality of the Egyptian coastal environment and the risk for consumers especially along the Mediterranean Sea (Abdel Ghani et al., 2010; El-Shehawi et al., 2013; Suzuki et al., 2016). Alexandria City is known to be the largest city following Cairo, Egypt and it is located in the southeast of Mediterranean coast. Alexandria encounters about 40 $\%$ of the total Egyptian industrial activities. The coastal waters of Alexandria received extensive discharges of untreated agricultural, industrial and sewage wastewaters in the last four decades. It was found that $183 \times 106 \mathrm{~m}^{3}$ of untreated domestic sewage in addition to wastewaters were discharged annually from land-based sources to Alexandria

\footnotetext{
${ }^{*}$ Corresponding authors:

Giulia Guerriero, EClab, Department of Biology, University of Naples, Federico II, Naples, Italy. E-mail: giulia.guerriero@unina.it Fagr Kh. Abdel-Gawad, Department of Water Pollution, Centre of Excellence for Advanced Science Research, National Research Centre, Dokki, Giza, Egypt. E-mail: fagrabdlgawad@gmail.com
} 
coastal waters (Abdel-Gawad et al., 2015; Abdel-Gawad et al., 2018). It is well known that heavy metals pollution and accumulation becomes a major problem around the world due to many reasons; the toxicity, non-biodegradable properties, abundant sources in addition to their accumulative behaviour (Bartiromo et al., 2013; AbdelGawad et al., 2015; Adel et al., 2018). Fish are considered as a vital biosentinel for environmental pollution and precede a significant role in assessment of the potential risk associated with pollution of aquatic environment (Van der Oost et al., 2013). Aquatic biosentinels can represent an early warning when biomarkers of stress as evaluation of antioxidative physiological defense by chromatography (Guerriero et al., 2003); enzymatic activity assay (Guerriero et al., 2002; Guerriero et al., 2004; Guerriero et al., 2018); morphological or ultrastructural studies (Scalici et al., 2017; Pecoraro et al., 2017, 2018); immunohistochemistry (Guerriero et al., 2017a); pattern and expression of steroid hormones and their receptors alteration (Guerriero et al., 2005a,b; Guerriero 2007; Guerriero et al., 2009); free radicals detection using electron spin resonance electron (Guerriero et al., 2017b; D'Errico et al., 2018) or their DNA damage (Piscopo et al. 2010; Vassalli et al., 2015; Guerriero et al., 2017b) have been detected. Using enzymatic assay of the antioxidants, Gluthatione-S-transferase we can assay indirectly the oxidative stress. Glutathione S-Transferase enzymes (GSTs) consist of a series of cytosolic enzymes which are implicated in phase-II biotransformation of a major number of pollutants. Such enzymes are responsible of the catalysis conjugation of glutathione (GSH) to lipophilic compounds with electrophilic centres to neutralize then excrete some chemicals able to cause toxic impacts (Guerriero et al., 2017a). Nowadays, there are many enzyme groups or isoenzymes were reported while some of them vary among different animals and their tissues (Angellucci et al., 2000; Novoa-Valinas et al., 2002). Glutathione S-transferase is considered from the most functional phase-II biotransformation pathways in vertebrates and invertebrates for potentially toxic chemicals. Also, GST was characterized in several species; gastropods, polychaetes, mussels, crustaceans in addition to fish (Hylland et al., 2006). The GST isoenzymes could be induced by different pollutants and many studies reported increased hepatic activity after exposure to toxic chemicals (see for review, Perez-Lopez et al., 2002). Based on previous studies it was stated that GST induction is considered to be adopted as a biomarker for exposure to different pollutants; PAHs, PCBs and Dioxins (Abdel-Gawad et al., 2014; Abdel-Gawad et al., 2015; Abdel-Gawad et al., 2018). Although the activity of GST was determined in diverse tissues, detection of GST is preferred to be performed on tissues of high biotransformation activity. The most valuable tissues for GST determination are liver tissues of vertebrates, the hepatopancreas and digestive gland in invertebrates, besides fish gills which considered the primary line of defence against water pollutants (Hylland et al., 2006). Recently, comet assay is known as a simple, rapid, reliable and standard technique for measuring DNA damage in fish exposed to different pollutants (Abdel-Gawad et al., 2011; Bhagat et al., 2016; Abdel et al., 2018). The comet assay is extensively used in genotoxicity evaluation of different substances; pharmaceuticals, agrochemical, food additives and industrial chemicals (Brendler-Schwaab et al., 2005; Guilherme et al., 2009). Oxidative enzymes are also used as a biomarker for toxicity assessment of many water pollutants (Fasulo et al., 2015). The aim of the present study was to evaluate the biological responses to the effect of marine pollution in different sites in Alexandria coast using water and sediment analysis, the detossification and the genotoxicity in fish (muscle, liver and gills) as the white sea bream (Diplodus sargus) and the sardine (Sardine pilchardus) for food security advice.

\section{MATERIALS AND METHODS}

\section{Samples collection}

Samples were collected from different points of Alexandria shore: El-Max, Bahary and El-Shatby (Fig. 1) and then transferred to the Biotechnology and Biodiversity Conservation laboratory, Centre of Excellence for Advanced Sciences, National Research Centre. Sampled fish were dissected, barcoded following Di Finizio et al., (2007) and the tissues (gills, liver and muscle) aliquoted from 30 fishes of each species/sites were used for analyses. White sea bream (Diplodus sargus) and sardine (Sardine pilchardus) were collected from El-Max and Bahary while sardine was sampled from El-Shatby that may be considered as a reference point.

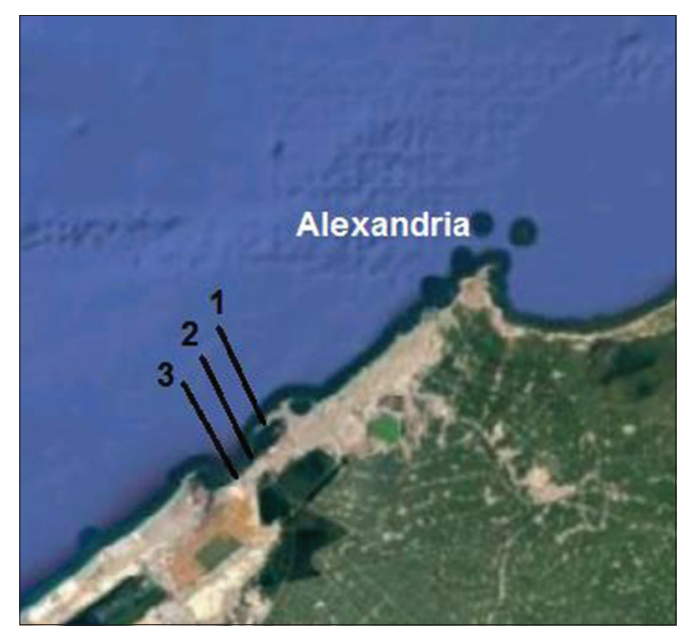

Fig 1: Sampling sites from Alexandria (Egypt): 1, Bahary; 2, El-Shatby and 3, El-Max. 
Table 1: Physical and chemical analysis of water samples

\begin{tabular}{|c|c|c|c|c|c|c|c|c|c|c|c|}
\hline Parameter & $\begin{array}{c}\mathrm{Al} \\
(\mathrm{mg} / \mathrm{L})\end{array}$ & $\begin{array}{c}\mathrm{Cd} \\
(\mathrm{mg} / \mathrm{L})\end{array}$ & $\begin{array}{c}\mathrm{Cr} \\
(\mathrm{mg} / \mathrm{L})\end{array}$ & $\begin{array}{c}\mathrm{Fe} \\
(\mathrm{mg} / \mathrm{L})\end{array}$ & $\begin{array}{c}\mathrm{Pb} \\
(\mathrm{mg} / \mathrm{L})\end{array}$ & $\begin{array}{c}\mathrm{Hg} \\
(\mathrm{mg} / \mathrm{L})\end{array}$ & $\mathrm{pH}$ & $\begin{array}{c}\mathrm{DO} \\
\mathrm{ml} \mathrm{\textrm {O } _ { 2 }} / \mathrm{L} \\
\end{array}$ & TDS & Turbidity (NTU) & Phenol (mg/l) \\
\hline El-Max & $<0.01$ & $<0.001$ & $<0.001$ & 0.04 & $<0.001$ & $<0.001$ & 7.9 & 4.6 & 43000 & 6.2 & N.D \\
\hline Bahary & $<0.01$ & $<0.001$ & $<0.001$ & 0.05 & $<0.001$ & $<0.001$ & 8.3 & 5.5 & 43000 & 4 & N.D \\
\hline El-Shatby & $<0.01$ & $<0.001$ & $<0.001$ & 0.08 & $<0.001$ & $<0.001$ & 7.9 & 7.5 & 44000 & 4.1 & N.D \\
\hline
\end{tabular}

Table 2: Chemical analysis of sediment

\begin{tabular}{lcccccc}
\hline Parameter & Al & Cd & Cr & Fe & Pb & Hg \\
\hline El-Max & 1975 & $<0.001$ & 19.75 & 1950 & 19.25 & $<0.05$ \\
Bahary & 900 & $<0.001$ & 8.25 & 1725 & 11 & $<0.05$ \\
El-Shatby & 950 & $<0.001$ & 2.5 & 1175 & 6.5 & $<0.05$ \\
\hline
\end{tabular}

\section{Water and sediment analysis}

Water and sediment were collected from Alexandria shore (as shown in Table 1 and Table 2) at El-Max, Bahary; and Shatby as a control point. Water and sediment samples were transferred to the Biotechnology and Biodiversity Conservation laboratory, Centre of Excellence for Advanced Sciences, National Research Centre. Water and sediment analysis involved the following: Aluminum (Al), Cadmium (Cd), Chromium (Cr), Iron (Fe), Lead (Pb), Mercury (Hg), pH, Dissolved Oxygen (DO), Total dissolved solids (TDS), Turbidity and Phenol. In water, $\mathrm{pH}$ and conductivity too. Water and sediment samples were measured referring to Standards Methods for the Examination of Water and Wastewater (2012).

\section{Enzyme Assay for Glutathione S-Transferase}

The Glutathione-S-Transferase (GST) activity was measured in liver samples isolated from barcoded fish collected from different localities from Alexandria as mentioned before. The samples were treated following the protocol established by Habig and Jakoby (1981). Liver samples were homogenized in (50 mM Tris- $\mathrm{HCl}, 0.15 \mathrm{M}$ $\mathrm{KCl}, \mathrm{pH}$ 7.4) buffer (1:4 volumes), then centrifuged for $30 \mathrm{~min}$ at $4^{\circ} \mathrm{C}$ at $9,000 \mathrm{~g}$. To get the cytosolic fraction, which used for enzymatic activity analysis of GST, a fraction from supernatant was separated and centrifuged for $60 \mathrm{~min}, 4^{\circ} \mathrm{C}$ at $37,000 \mathrm{~g}$. Bovine serum albumin was used as a standard to determine the protein concentration of supernatant. The activity of GST was assessed referring to the method described by Habig and Jakoby (1981), which is mainly based on conjunction of $1 \mathrm{mM}$ of 1-chloro-2,4dinitrobenzene (CDNB; Sigma) with $1 \mathrm{mM}$ glutathione (Sigma). The enzymatic activity was detected as absorbance increments $(340 \mathrm{~nm})$ and it was expressed in units, that 1 unit represents the amount of enzyme necessary to conjugate $1 \mu \mathrm{mol}$ of $\mathrm{CDNB} / \mathrm{min} / \mathrm{mg}$ protein, at $25^{\circ} \mathrm{C}$ and $\mathrm{pH}$ 7.00. The activity of GST is expressed as $\mu \mathrm{mol} \mathrm{\textrm {min } ^ { - 1 }}$ $\mathrm{mg}^{-1}$ of protein.

\section{Analysis of DNA damage, Comet Assay}

Immediately after fish dissection, small sections of gills, liver and muscle tissues were transferred into RPMI medium then cellular dissociation was done according to Cavalcante et al. (2008). Comet assay was done under alkaline conditions referring to Singh et al. (1988).

\section{Statistical analyses}

Data analysis was done through statistical analysis which was performed using the General Liner Models (GLM) procedure of Statistical Analysis System. After that the Scheffe'-test was performed to detect significant differences among fish samples. The values expression was revealed as mean \pm SEM. Statements of significant were based mainly on the probability of $\mathrm{P} \leq 0.05$ compared to control area (El-Shatby).

\section{RESULTS AND DISCUSSION}

\section{Water and sediment analysis}

Dissolved oxygen levels are strongly influenced by pollution as if the level falls to $2 \mathrm{mg} / 1$, acute physiological stress occurs to marine biota that may lead to death. For such reason, DO amount in water is considered a good indicator for its quality. In the present study DO level drops below $5 \mathrm{ml} \mathrm{O}_{2} / \mathrm{L}$ only in El-Max bay that may be due to its pollution with different contaminants while in El-Shatby DO level reached $7.5 \mathrm{ml} \mathrm{O}{ }_{2} / \mathrm{L}$ (Hussein et al., 2013). Although trace metals (e.g. zinc, selenium and copper) are vital to maintain the human body metabolism, their elevated concentrations cause toxic effects. Some other metals are toxic even in low concentrations (e.g. cadmium, lead and mercury) (Piscopo et al., 2018). Referring to chemical characteristics if metals, trace metals are persistent in environment, as in many cases they just change the chemical state and accumulate in food chain (Llobet et al., 2007; Hussein et al., 2013; Okbah et al., 2016). The concern about accumulation and human health is widely reported (Marti-Cid et al., 2007; Sharma et al., 2014).

The distribution of some heavy metals in water and sediment isolated from Alexandria coast is represented in tables 1 and 2 . Trace metals were not detected in water samples while turbidity was higher in samples collected 
from El-Max than other sites. Concerning sediment samples, it can be seen that trace elements concentrations reached their maximum rates in sediment samples collected from El-Max followed by samples collected from Bahary and El-Shatby. The metals concentrations in sediment may be ordered as follows: $\mathrm{Al}>\mathrm{Fe}>\mathrm{Cr}>\mathrm{Pb}>\mathrm{Hg}>\mathrm{Cd}$. Our results correlated with previous studies on El-Max in Alexandria (Abdallah et al., 2008; Soliman et al., 2015; Saad et al., 2017). The high iron concentrations in our results may be due to organic matter and wastes reached the bay from El-Umum Drain (Ghanem et al., 2015). Okbah et al. (2016) studied heavy metals distribution in El-Max bay sediments and metals content decreased in the following order: $\mathrm{Fe}>\mathrm{Mn}>\mathrm{Zn}>\mathrm{Pb}>\mathrm{Cu}>\mathrm{Cd}$. El-Max bay is well known to receive different pollution discharges that affected heavy metals concentrations, especially that domestic untreated wastewater may be considered from the major sources of observed heavy metals contamination (Zaqoot et al., 2017). Sediments of water bodies preserve contaminants for several years so may affect human health in addition to surrounding environment and so deserve special consideration in designing any aquatic food study (Sharma et al., 2014; Adel et al., 2018). Sediments are considered an essential basin of contaminants assessment and also a supplemented source for benthic organisms especially in estuarine ecosystems (Wang et al., 2007; Abdel-Gawad et al., 2018). The risk for consumers is usually monitored and daily intake can be adopted for limiting human pathologies (Sharma et al., 2014; Adel et al., 2018).

\section{Enzyme Assay for Glutathione S-Transferase}

The data analysis of GST activity as a biomarker of marine pollution in sampled barcoded fish was represented in Fig. 2. The greatest values of liver GST activity were recorded in white sea bream (Diplodus sargus) and sardine (Sardine pilchardus) isolated from El-Max in isolated followed by samples isolated from Bahary. Fish collected from El-Shatby encounter the lowest enzyme activity. Sardine isolated from El-Max showed the highest GST concentration among all sampled fish from different localities. As we know the answer is related to the species of fish and very useful was barcoded the fish analyzed following Di Finizio et al., (2007). As seen in the present analysis, we can summarize that enzyme activity is correlated with pollution and so El-Max is more polluted than Bahary and El-Shatby. Unfortunately, El-Max encountered many pollution sources as mentioned in many previous researches (Okbah et al., 2016; Zaqoot et al., 2017).

From the most important biochemical biomarkers used recently for pollution assessment in fish are some enzymes related to detoxification of toxic tools and their metabolites. Enzymes from the family of Glutathione-S-Transferase (GST) are considered very important for protection against any damage resulted from potentially reactive compounds to be combined with endogenous molecules, so finally removed by the body (D'Errico et al., 2018). The enzyme activity is known to be a vital biomarker of exposure to different environmental pollutants either terrestrial or aquatic (Fasulo et al., 2015; Guerriero et al., 2017 a,b).

\section{Evaluation of DNA Damage}

DNA damage was estimated by using comet assay to detect DNA strand breaks in nuclei from (gills, liver and muscle) of barcoded White Sea Bream (Diplodus sargus) and Sardine (Sardine pilchardus) fish sampled from El-Max bay, Bahary and El-Shatby, Alexandria coast (Fig. 3). DNA strand breaks detected by comet assay could be present during cell repairs lesions through nucleotide excision. So, detection of high

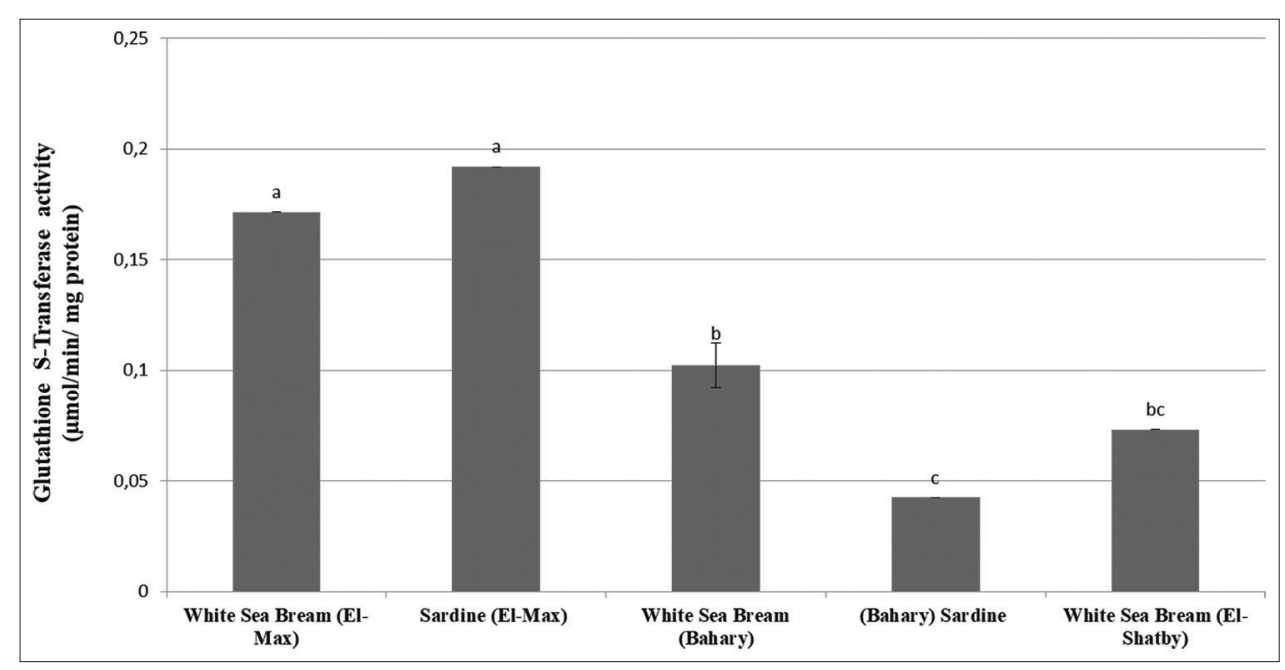

Fig 2: Glutathione S-Transferase activity in liver of fishes ( $n=30 /$ each species) isolated from different localities in Alexandria. Different letters (a, $\mathrm{b}$ and $\mathrm{c})$ are significantly different $(\mathrm{P}<0.05)$ compared to the control group. 
ratios of DNA breaks in comet assay indicates either elevated damage rate or repair approach (Collins et al., 1997; AbdelGawad et al., 2015). It can be seen that DNA damage reached the highest percentages in El Max site followed by Bahary area and the least were detected in El-Shatby. When comparing the DNA damage among sampled fish for the same area it's clear that; white Sea bream showed DNA damage levels more than Sardine fish. The different answer to xenobiotics is related to the species-specificity and this is the reason why it is important the samples discrimination (Di Finizio et al., 2007; Mazzeo 2008; Guerriero et al., 2017c) Previous studies also indicated that El-Max bay is considered from the highly polluted sites when compared to other sites in Alexandria coast (Saad et al., 2017). El-Max bay suffered from continuous major drastic changes resulting from human activities; untreated industrial waste, domestic sewage, shipping industry and agricultural runoff which are being released into the bay (Abo-Taleb et al., 2015). Such activities have pronounced harmful impacts on marine fish filet sampled in our study. Referring to fish tissues and organs, it can be realized that gills followed by liver show more rates of DNA damage than filet in all sampled fish from different localities. The comet assay is an important tool used in environmental biomonitoring using fish as a model as it can presents rapid screening system to be adopted in biomonitoring food programs for detecting genotoxic potential as in environmental studies (Sharma et al., 2007; Nagpure et al., 2008; Abdel-Gawad et al., 2014; Abdel-Gawad et al., 2018).

\section{CONCLUSION}

Toxicological studies highlight that metals represent the most oral consumption at high risk for human reporting risk assessment and health implications. The results of the present research on the genotoxic and mutagenic potential of polluted marine water of Alexandria coast, in Egypt suggested a sitespecificity concern about the oral comsumption of some marine fish. The white sea bream (Diplodus sargus) and sardine (Sardinepilchardus) biological responses indicated the importance and the sensitivity of oxidative stress biomarkers assessment as insight in the safety issue for species-specificity and tissuespecificity. The first rapid extimation in the monitoring food programs can be useful done using the enzymatic activity of Glutathione S-Transferase by spectrophotometer and DNA damage using comet assay.

\section{ACKNOWLEDGMENTS}

This work was supported by the Biotechnology and Genetic Conservation group laboratory, Water Pollution Research Centre of Excellence for Advanced Sciences (CEAS), National Research Centre, Egypt. Deep appreciation for the experimental participation at National Research Centre (Dokki, Giza) of Dr. Giulia Guerriero, Visiting Professor in the framework of MoU between the National Research Centre of Giza and the Federico II University of Naples, Italy.

\section{Author contributions}

All authors contributed to conception and design of the experiments. All the authors have given their approval to the final version of the manuscript.

\section{Compliance with ethical standards}

The research described herein was performed on white sea bream (Diplodus sargus) and sardine (Sardine pilchardus).

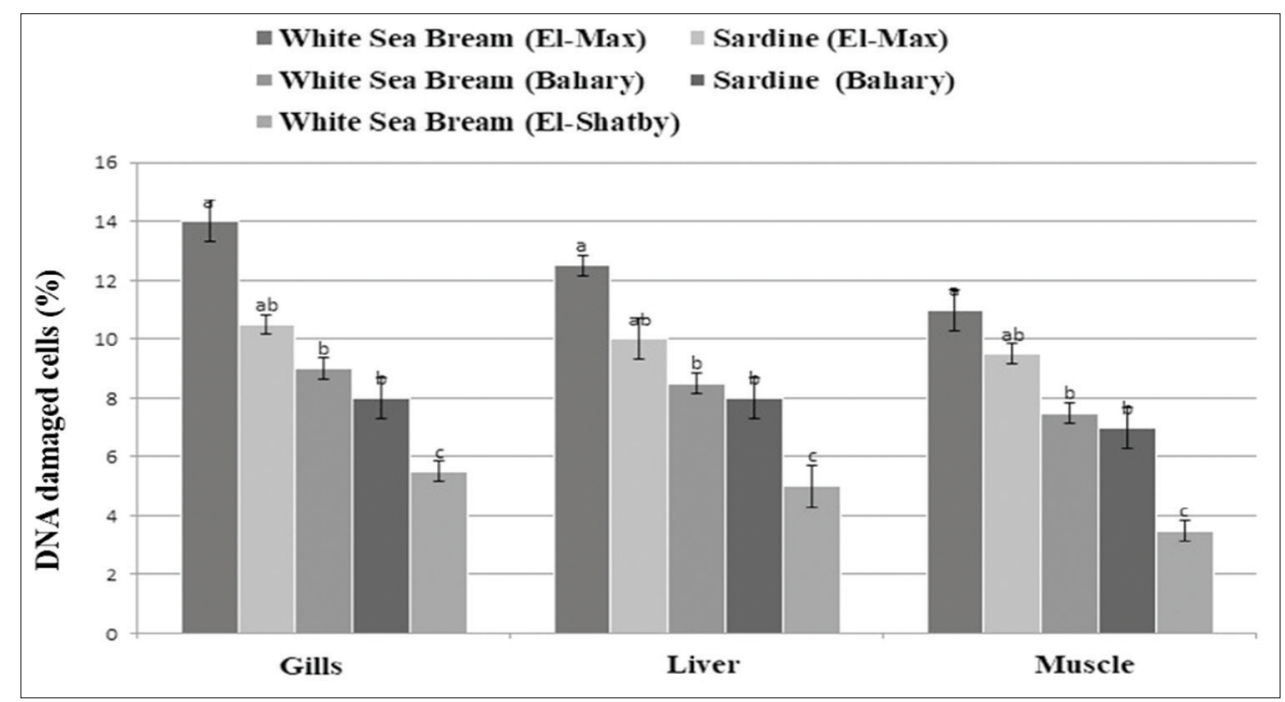

Fig 3: DNA damage in gills, liver and muscle of fishes ( $n=30 /$ each species) collected from different sites in Alexandria. Different letters ( $a$, $b$ and c) are significantly different $(\mathrm{P}<0.05)$ compared to the control group. 
This study was conducted in strict accordance with the guidelines of the Ethical Committee, National Research Centre, Egypt on the care and use of animals for scientific purposes.

\section{CONFLICT OF INTEREST}

The authors declare that they have no conflict of interest.

\section{REFERENCES}

Abdallah, M. A. M. (2008). Trace metal behavior in mediterraneanclimate coastal bay: El-mex bay, Egypt and its coastal environment. Glob. J. Environ. Res. 2(1): 23-29.

Abdel Ghani G. S. A., A. H. Shobier, T. O. Said and M. A. Shreadah, MA. (2010). Organotin compounds in Egyptian mediterranean sediments. Egyp. J. Aquat. Res. 36: 221-229.

Abdel-Gawad, F. K., W. K. B. Khalil, A. A. El-Kady, A. I. Waly and M. A. Abdel-Wahhab. (2016). Carboxymethyl chitosan modulates the genotoxic risk and oxidative stress of perfluorooctanoic acid in Nile tilapia (Oreochromis niloticus). J. Saudi Soc. Agr. Sci. 15: $57-66$.

Abdel-Gawad, F. K., N. M. Lotfy, M.A. Hassanein and S. M. Bassem. (2011). Evaluation of DNA damage in fish and aquatic insects induced by environmental pollutants in river Nile. World Appl. Sci. J. 14(7): 1085-1090

Abdel-Gawad, F. K., O. Osman, S. M. Bassem, H. F. Nassar, T. A. Temraz, H. Elhaes and M. Ibrahim. (2018). Spectroscopic analyses and genotoxicity of dioxins in the aquatic environment of Alexandria. Marine Poll. Bull. 127: 618-625.

Abdel-Gawad, F. K., G. Guerriero, S. M. Basem and N. F. Nassar. (2015). Toxicogenomics for water quality assessment. Der Pharm. Chem. 7(12): 377-381.

Abdel-Gawad, F. K., H. F. Nassar, S. M. Bassem, G. Guerriero and W. K. B. Khalil. (2014). Effect of polycyclic aromatic hydrocarbons (PAHs) on modulate genes encoding stress-related proteins and antioxidant enzymes in different marine fish species of Red Sea Water. World Appl. Sci. J. 32(12): 2337-2346.

Abo-Taleb, H. A., M. El Raey, M. M. Abou Zaid, S. M. Aboul Ezz and N. E. Abdel Aziz. (2015). Study of the physicochemical conditions and evaluation of the changes in eutrophication-related problems in El- Mex Bay. Afr. J. Environ. Sci. Technol. 9 (4): 354-364.

Adel, M., C. Copat, M. R. Saeidi, G. O. Conti, M. Babazedeh and M. Ferrante M. (2018). Bioaccumulation of trace metals in banded Persian bamboo shark (Chiloscyllium arabicum) from the Persian Gulf: A food safety issue. Food Chem. Toxicol. 11: 198-203.

Adel, M, C. G. Oliveri, M. Dadar, M. Mahjoub and C. Copat. (2016). Heavy metal concentrations in edible muscle of whitecheek shark, Carcharhinus dussumieri (Elasmobranchii, Chondrichthyes) from the Persian Gulf: A food safety issue. Food Chem. Toxicol. 97: 135-140.

Angellucci, S., P. Sacchetta, P. Moio, S. Melino, R. Petruzzelli, P. Gervasi and C. Di Ilio. (2000). Purification and characterization of glutathione transferases from the sea bass (Dicentrarchus labrax) liver. Arch. Biochem. Biophys. 373: 435-441.

Bartiromo, A, G. Guignard, M. R. Barone Lumaga, F. Barattolo, G. Chiodini, R. Avino, G. Guerrier and G. Barale. (2013). The cuticle micromorphology of in situ Erica arborea L. Exposed to long-term volcanic gases. Environ. Exp. Botany. 87: 197-206.

Bhagat, J, A. Sarkar and B. S. Ingole. (2016). DNA damage and oxidative stress in marine gastropod morula granulata exposed to phenanthrene. Water Air Soil Pollut. 227: 114.

Brendler-Schwaab, S, A. Hartman, S. Pfuhler and G. Speit. (2005). The in vivo comet assay: Use and status in genotoxicity testing. Mutagenesis. 20: 245-254.

Cavalcante, D. G. S. M., C. B. R. Martinez and S. H. Sofia. (2008). Genotoxic effects of roundup on the fish Prochilodus lineatus. Mutat. Res. 655: 41-46.

Collins, A. R, V. L. Dobson, M.Dusinska, G. Kennedy and R. Stetina. (1997). The comet assay: What it can really tell us. Mutat. Res. 375: 183-193.

Conti, G. O, C. Copat, and C. Ledda. (2012). Evaluation of heavy metals and polycyclic aromatic hydrocarbons (PAHs) in Mullus barbatus from sicily channel and risk-based consumption limits. Bull. Environ. Contam. Toxicol. 88: 946.

D’Errico, G., G. Vitiello, G. De Tommaso, F. K. Abdel-Gawad, M. V. Brundo, M.Ferrante, A. De Maio, S. Trocchia, A. R. Bianchi, G. Ciarcia and G. Guerriero. (2018). Electron spin resonance (ESR) for the study of reactive oxygen species (ROS) on the isolated frog skin (Pelophylax bergeri): A non-invasive method for environmental monitoring. Enviro. Res. 165: 11-18.

Di Finizio, A., G. Guerriero, G. L. Russo and G. Ciarcia. (2007). Identification of gadoid species (Pisces, Gadidae) by sequencing and PCR-RFLP analysis of mitochondrial $12 \mathrm{~S}$ and $16 \mathrm{~S}$ rRNA gene fragments. Eur. Food Res. Technol. 225: 337-344.

El-Shehawi, A. M., F. K. Ali and M. A. Seehy. (2013). Estimation of water pollution by genetic biomarkers in tilapia and catfish species shows species-site interaction. Afr. J. Agr. 1(1):1-7.

Fasulo, S., G. Guerriero, S. Cappello, M. Colasanti, T. Schettino, C. Leonzio, G. Mancini and R. Gornati. (2015). The systems biology in the study of xenobiotic effects on marine organisms for evaluation of the environmental health status: Biotechnological applications for potential recovery. Rev. Environ. Sci. Biotechnol. 14: 339-345.

Ghanem, M. H., S. M. Shehata, J, M. M. Abu-Zaid, A. M. Abdel-Halim and M. M. Abbas. (2015). Accumulation of some heavy metals in the muscles of Diplodus sargus, inhabiting El-Mex Bay (Alexandria, Mediterranean Sea) with special references to its physiological responses. Int. J. Environ. Sci. Eng, 6: 1-13.

Guerriero, G., S. M. Bassem, W. K. B. Khalil, T. A. Temraz, G. Ciarcia and F. K. Abdel-Gawad. (2018). Temperature changes and marine fish species (Epinephelus coioides and Sparus aurata): Role of oxidative stress biomarkers in toxicological food studies. Emir. J. Food Agr. 30: 205-211.

Guerriero, G., M. V. Brundo, S. Labar, A. R. Bianchi, S. Trocchia, D. Rabbito, G. Palumbo, F. K. Abdel-Gawad, and A. De Maio. (2017a). Frog (Pelophylax bergeri, Günther 1986) endocrine disruption assessment: Characterization and role of skin poly (ADP-ribose) polymerases. Environ. Sci. Pollut. Res. 21: 2.

Guerriero, G., G. D'Errico, R. Di Giaimo, D. Rabbito, O. S. Olanrewaju and G. Ciarcia. (2017b). Reactive oxygen species and glutathione antioxidants in the testis of the soil biosentinel Podarcis sicula (Rafinesque 1810). Environ. Sci. Pollut. Res. 25: 18286-18296.

Guerriero, G., D. Rabbito, M. A. Alwany, A. Madonna, T. A. Temraz, S. O. Olanrewaju, S. M. Bassem, S. Trocchia, F. K. Abdel-Gawad and G. Ciarcia. (2017c). Fisheries and biodiversity along Mediterranean sea: Italian and Egyptian coast overview. Euro. Medit. J. Environ. Integrat. 2: 16.

Guerriero, G., C. E. Roselli and G. Ciarcia. (2009). The amphibian (Rana esculenta) brain progesterone receptor: Relationship to plasma steroids and vitellogenic cycle during the gonadal recovery phase. Ann. N Y Acad. Sci. 1163: 407-409.

Guerriero, G. (2007). Seasonal steroids variations and maturity stages in the female chub, Leuciscus cephalus L. (Pisces, Cyprinidae). Italian J. Zool. 74(4): 317-324.

Guerriero, G., G. S. Prins, L. Birch and G.Ciarcia. (2005a). Neurodistribution 
of androgen receptor immunoreactivity in the male frog, Rana esculenta. Ann. N. Y. Acad. Sci. 1040: 332-336.

Guerriero, G., R. Ferro and G. Ciarcia, G. (2005b). Correlation between plasma levels of sex steroids and spermatogenesis during the sexual cycle in the chub, Leuciscus cephalus L. (Pisces: Cyprinidae). Zool. Stud. 44: 228-233.

Guerriero, G., R. Ferro, G. L. Russo and G. Ciarcia, G. (2004). Vitamin E in early stages of sea bass (Dicentrarchus labrax) development. Comp. Biochem. Phys. 138(4): 435-439.

Guerriero, G., A. Di Finizio and G. Ciarcia.(2003). Oxidative defenses in the sea bass, Dicentrarchus labrax. In: Dunn, J. F., Swartz H. M., editors. Oxygen Transport to Tissue XXIV. Advances in Experimental Medicine and Biology. Springer, Boston, MA, p. 681-688.

Guerriero.,G, A. Di Finizio and G. Ciarcia. (2002). Stress-induced changes of plasma antioxidants of aquacultured sea bass, Dicentrarchus labrax. Comp. Biochem. Physiol. 132: 205-211.

Guilherme, S., I. Gaivao, M. A. Santos and M. Pacheco. (2009). Tissuespecific DNA damage in the European eel (Anguilla anguilla) following a short-term exposure to a glyphosate-based herbicide. Toxicol. Lett. 189S: Z15.

Habig, W. H. and W. B. Jakoby. (1981). Mechanism for several activities of the glutathione S-transferases. J. Biol. Chem. 251: 6183-6188.

Hussein, R. A., M. Y. El-Aziz, A. K. Arafa, and O. D. El-Sebaie. (2013). Impact of Alexandria corniche road widening on Mediterranean sea water quality. Egypt Bull. 43(2): 175-184.

Hylland, K., M. Grung, A. Ruus, K. E. Tollefsen, J. F. Børseth, L. P. Myhre, R. Bechmann and J. Barsiene. (2006). Biomarkers in monitoring a review. Norwegian Institute for Water Research, Serial No. 5205-200. Report No. O-25302. p. 106.

Llobet, J. M., G. Falco, A. Bocio and J. L. Domingo. (2007). Human exposure to polychlorinated naphthalenes through the consumption of edible marine species. Chemosphere. 66: 1107-1113.

Marti-Cid, R., A. Bocio, J. M. Llobet and J. L. Domingo. (2007). Intake of chemical contaminants through fish and seafood consumption by children of Catalonia, Spain: Health risks. Food Chem. Toxicol. 45: 1968-1974.

Mazzeo, M. F., B. De Giulio, G. Guerriero, G. Ciarcia, A. Malorni, G. L. Russo and R. A. Siciliano. (2008). Fish authentication by Maldi-t of mass spectrometry. J. Agric. Food. Chem. 56: 11071-11076.

Nagpure, N. S., S. Sharma, S. Pandey, R. Kumar, K. S. Satish, M. S. Verma and D. Kapoor., (2008). Use of comet assay for genotoxicity assessment in fishes from Gomti River. Indian J. Fish. 55(3): 285-288.

Novoa-Valinas, M. C., M. Perez-Lopez and M. J. Melgar. (2002). Comparative study of the purification and characterization of the cytosolic glutathione S-transferases from two salmonid species: Atlantic salmon (Salmo salar) and brown trout (Salmo trutta). Comp. Biochem. Physiol. C. 131: 207-213.

Okbah, M. A., M. Masoud, G. M. El Zokm and A. A. Abd El-Salam. (2016). Heavy metals distribution in water, particulate and sediment of El-Mex Bay, Alexandria, Egypt. J. Energ. Environ. Chem. Eng. 1(1): 1-12.

Pecoraro, R., F. Marino, A. Salvaggio, F. Capparucci, G. Di Caro, C. Iaria, A. Salvo, A. Rotondo, D. Tibullo, G. Guerriero, E. M. Scalisi, M. Zimbone, G. Impellizzeri and M. V. Brundo. (2017). Evaluation of chronic nanosilver toxicity to adult zebrafish. Front Physiol. 8: 1011.

Pecoraro, R., D. D'Angelo, S. Filice, S. Scalese, F. Capparucci, F. Marino, C. Iaria, G. Guerriero, D. Tibullo, E. M. Scalisi, A. Salvaggio, I. Nicotera and M. V. Brundo. (2018). Toxicity evaluation of graphene oxide and titania loaded nafion membranes in zebrafish. Front Physiol.
8: 1039.

Perez-Lopez, M., M. C. Novoa-Valinas and M. J. Melgar-Riol. (2002). Glutathione S-transferase cytosolic isoforms as biomarkers of polychlorinated biphenyl (Arochlor-1254) experimental contamination in rainbow trout. Toxicol. Lett. 136: 97-106.

Piscopo, M., R. Notariale, D. Rabbito, J. Ausió, O. S. Olanrewaju and G. Guerriero. (2018). Mytilus galloprovincialis (Lamarck, 1819) spermatozoa: Hsp70 expression and protamine-like protein property studies. Environ. Sci. Pollut. Res. Int. 25: 12957-12966.

Piscopo, M., M. Conte, F. Di Paola, S. Conforti, G. Rana, L. De Petrocellis, L. Fucci and G. Geraci. (2010). Relevance of arginines in the mode of binding of H1 histones to DNA. DNA Cell Biol. 29(7): 1-9.

Saad, A. S., M. A. Massoud, R. A. Amer and M. A. Ghorab. (2017). Assessment of the physico-chemical characteristics and water quality analysis of Mariout Lake, Southern of Alexandria, Egypt. J. Environ. Anal. Toxicol. 7: 421.

Scalici, M., L. Traversetti, F. Spani, V. Malafoglia, M. Colamartino, T. Persichini, S. Cappello, G. Mancini, G. Guerriero and M. Colasanti. (2017). Shell fluctuating asymmetry in the sea-dwelling benthic bivalve Mytilus galloprovincialis (Lamarck, 1819) as morphological markers to detect environmental chemical contamination. Ecotoxicology. 26: 396.

Sharma, B., S. Singh and N. J. Siddiqi. (2014). Biomedical implications of heavy metals induced imbalances in redox systems. Biomed. Res. Int. 2014: 640754.

Sharma, S., N. S. Nagpure, R. Kumar, S. Pandey, S. K. Srivastava, P. J. Singh and P. K. Mathur. (2007). Studies on the genotoxicity of endosulfan in different tissues of freshwater fish Mystus vittatus, using the comet assay. Arch. Environ. Contam. Toxicol. 53: 617-623.

Singh, N. P., M. T. McCoy, R. R. Tice and E. L. Schneider. (1988). A simple technique for quantification of low levels of DNA damage in individual cells. Exp. Cell Res. 175: 184-191.

Soliman, N. F., S. M. Nasr and M. A. Okbah. (2015). Potential ecological risk of heavy metals in sediments from the Mediterranean coast, Egypt. J. Environ. Health Sci. Eng. 13(70): 1-12.

Standard Methods for the Examination of Water and Wastewater. (2012). American Public Health Association. $22^{\text {nd }}$ ed. Washington, D.C.

Suzuki, N., M. Sato, H. F. Nassar, F. K. Abdel-Gawad, S. M. Bassem, K. Yachiguchi, Y. Tabuchi, M. Endo, T. Sekiguchi, M. Urata, A. Hattori, H. Mishima, Y. Shimasaki, Y. Oshima, C. S. Hong, F. Makino, N. Tang, A. Toriba and K. Hayakawa. (2016). Seawater polluted with highly concentrated polycyclic aromatic hydrocarbons suppresses osteoblastic activity in the scales of goldfish, Carassius auratus. Zool. Sci. 33(4): 407-13.

Van der Oost, R., J. Beyer and N. P. E. Vermeulen. (2003). Fish bioaccumulation and biomarkers in environmental risk assessment: A review. Environ. Toxicol. Pharm. 13: 57-149.

Vassalli, Q. A., F. Caccavale, S. Avagnano, A. Murolo, G. Guerriero, L. Fucci, J. Ausió and M. Piscopo. (2015). New insights into protamine-like component organization in mytilus galloprovincialis' sperm chromatin. DNA Cell Biol. 34: 162-169.

Wang, X. C., Feng, H and Ma, HQ. (2007). Assessment of metal contamination in surface sediments of Jiaozhou Bay, Qingdao, China. Clean-Soil, Air, Water. 35(1): 62-70.

Zaqoot, H. A., A. M. Aish and H. N. Wafi. (2017). Baseline concentration of heavy metals in fish collected from gaza fishing harbor in the Mediterranean Sea along Gaza Coast, Palestine. Turk. J. Fish. Aquat. Sci. 17: 101-109. 